УДК: 371.3

DOI https://doi.org/10.32836/2521-6473.2021-4.3

Ewelina Gee-Milan, Director of the Student Clinic of Law

at Łazarski University, Academic Teacher

in the Department of Law and Civil Procedure

Julia Kujda, Student of the Faculty

of Law and Administration, Łazarski University

Zuzanna Stefańska, Student at LXV General

Joseph Bem Common Integration School Warsaw

\title{
STREET LAW IN THE 21st CENTURY. ASSUMPTIONS OF A STREET LAW SCHOOL CLINIC PILOT PROJECT
}

The aim of this article is to familiarize the reader with the assumptions of the pilot project, the main goal of which is to create the first School Law Clinic of Street Law in Poland. The clinic seeks to unite teachers, students and the academic community to promote a positive contribution to public affairs, to further develop Legal Clinics in Poland in the 21st century, and to supports schools and university staff to meet the learning outcomes indicated in the Polish Qualifications Framework, and more generally to increase the quality of education in schools and universities. In the article, the authors attempt to describe the aims of the project, the composition of the project team, along with the required characteristics of the participants, the expected beneficial results of the project, and the expected general effects of the implementation of the pilot project.

Key words: street law, Legal Clinic, law, responsibility, partnership, positive involvement in public affairs. \section{Street Law \\ Е. Гі-Мілан, Ю. Куйда, С. Стефанська. Streеt Lаw в XXI столітті. Призначення пілотного шкільного проєкту \\ Мета иієї статті - ознайомити читача з призначенням пілотного проєкту, головною метою якого є створення} першої в Польщі шкільної юридичної клініки вуличного права. Клініка прагне об 'єднати викладачів, студентів та академічну спільноту для сприяння позитивному внеску у суспільні справи для подальшого розвитку юридичних клінік у Польщі у XXI ст., а також для підтримки шкіл та персоналу університетів у досягненні результатів навчання, зазначених у Польській рамиі кваліфікацій, $і$ в цілому для підвищення якості освіти в школах та університетах.

Пілотний проєкт, якому присвячено цю статтю, безперечно, є інноваційним проєктом, який може вплинути на подальші зміни у польських юридичних клініках, які стикаються з багатьма проблемами у ХХІ ст. Його великою перевагою є те, що він може бути реалізований без серйозних збоїв як у класі (офлайн), так і в режимі онлайн-навчання.

У статті досліджуються й інші ризики, пов'язані, наприклад, з оплатою додаткової залученості викладачів університетів. Установлено, щзо, незважаючи на те щзо проєкт може вимагати більшої участі співробітників, додаткові витрати не будуть високими, тобто придбання будь-яких матеріалів, необхідних для проведення заходів (папір, фломастери, матеріали для будівнищтва будинків для безпритульних тварин під час семінарів із прав тварин, підготовлених для молодших школярів), є мінімальними.

У статті автори намагаються описати цүілі проєкту, склад команди проєкту разом із необхіднии характеристиками учасників, очікуваними корисними результатами проєкту та очікуваними загальними наслідками впровадження пілотного проєкту.

Ключові слова: Street Law, Юридична клініка, право, відповідальність, партнерство, позитивна участь у державних справах.

\section{INTRODUCTION}

According to the annual ranking organized by the Foundation of University Legal Clinics and the daily newspaper Rzeczpospolita, the Legal Clinic operating at Lazarski University is generally considered to be one of the best Student Law Clinics - both among public and private universities in Poland. Undoubtedly, the Street Law project has been the strongest point of this Law Clinic at Lazarski University for years. Its strength and importance for the entire Law Clinic is evidenced by the fact that in the years 2016-2019 almost 10,000 high school students participated in Street Law classes. The success of this project was primarily the result of the various innovations that were implemented by the Legal Clinic. In particular, didactic experiments in the field of teaching law made access to justice more possible; encouraged diverse groups to actively participate in civil society and, above all, promoted positive participation in public life. The subject of this article is to present to the reader the organizational framework of an innovative pilot for Street Law run by the Law Clinic of Lazarski University, which was the organization of School Street Law Clinics that operated under the patronage of the Student Legal

(C) Ewelina Gee-Milan, Julia Kujda, Zuzanna Stefańska, 2021 
Clinic of Lazarski University. The article is the first in a series of articles that will examine the implementation of the project, its course and effects.

The project seems even more important, because:

a) on August $5^{\text {th }}, 2015$, the Polish Parliament passed an Act on free legal aid, free civic counseling and legal education, to which, despite constant lobbying attempts, Law Clinics were not included as entities operating in this field;

b) the core curriculum of secondary schools has changed, which means that in terms of the subject of knowledge about society (both at the primary and extended level), students will learn the basics of law;

c) both academics and teachers in schools are looking for new solutions that will help them meet the challenges posed by the Polish framework of qualifications at various levels of education;

d) the post-pandemic situation requires an introduction of such projects that can be successfully implemented in a face to face, online, hybrid or asynchronous form;

e) if academic centers want to meet the challenges of the labor market, they must devote more attention to developing soft skills, as these are valued skills for law students.

STREET LAW - WHAT IS IT?

"The name Street Law is registered in the USA by Street Law Inc of Washington DC. Street Law Inc is a nonprofit organization that promotes legal literacy and human rights. The term 'Street Law' has been adapted for use in the UK and is used in this context with Street Law Inc's knowledge [1]. The program was established at Georgetown University in Washington in 1972 and introduced at Natal University in Durban as a credit subject in 1987. [David McQuoid-Mason Street Law as a clinical program from The South African Experience with Particular Reference to the University of KwaZulu-Natal]. Professor McQuoid-Mason has defined it as "a clinical law program which trains law students to provide people with information about the law and how it can be used in daily life" [2]. In Poland, the 'Street Law' program has been implemented since 1995 under the name 'every day Law'. So far in Poland, these were projects involving students, who under the supervision of their tutors, prepared workshops for various groups of recipients, e.g., prisoners, students, or seniors.

\section{PROJECT DESCRIPTION}

The aim of the implemented pilot project is:

a) creating opportunities for researchers, practitioners, students, pupils, and teachers to work together to increase the understanding of the law and legal obligations among children and young people;

b) the implementation of the learning outcomes in the Polish qualification framework for students and high school students - including group work and communication;

c) the development of the teaching skills of the staff at Lazarski University; centers.

d) the developing of the skills of teaching staff of a Secondary School through their cooperation with academic

These goals will be achieved by creating a Street Law Clinic at a High School in which the following activities will be undertaken:

a) the joint preparation of workshops for students of four primary schools - workshops will be devoted to animal rights, fake news, and migration law;

b) conducting three academic seminars, two of which it is obligatory for the speakers to only use English as a working language;

c) conducting at least three meetings with those involved in street law development around the World;

d) if possible, joint speeches of pupils, students, and researchers at conferences;

e) the joint preparation of two academic articles, including one of a strictly research nature;

f) joint educational campaigns in social media - posts, graphics related to the subject of workshops, seminars, and other joint activities.

DESCRIPTION OF THE PROJECT PARTICIPANTS

The choice of the school for the pilot program was not accidental. Lazarski University has been cooperating with the selected high school for many years, both in the field of free legal counseling, legal education, and the development of classes with a legal profile. In the pilot project, the project team will consist of thirty-five people. Twenty people from the high school and fifteen university representatives. The exact composition will be as follows:

a) fourteen students from a legal class and one student from a European class, who has been involved in the project from the beginning;

b) three teachers (class teachers, who speak English at least at a basic level);

c) career counselor and tutor/psychologis;

d) ten students, who are members of the Law Clinic operating at Lazarski University;

e) five tutors from the Law Clinic of Lazarski University - including one with pedagogical qualifications in the degree of professional promotion of an appointed teacher and one with additional psychological education.

The number of participants was selected, so that it was possible to easily manage the quality of the project. Among the teachers at the Lyceum, class tutors, career counselor and tutor/psychologist as those teachers, whose 
duties include preparing students to choose their field of study, and where they hope to study. The school tutor/ psychologist will monitor the mental health of the students and support them in such aspects as coping with stress, failures, and possibly help with conflict management. An additional reason for selecting a high school teacher is at least a basic level of proficiency in the English language, while the students are expected to have a minimum of B1 proficiency in English. Knowledge of the English language by high school representatives is important because of the planned involvement of people involved in Street Law programs from around the World in the Clinic's seminars. The meetings will be conducted in English, which should bring an additional benefit of helping to improve the competences of all project participants in the use of a modern language and strengthening their awareness of having this skill. Moreover, the level of education will be considered, with students coming from different grades, i.e., from the first to the third grade, i.e., in the current school year they are students of the youngest students and the oldest students This is a principle which, according to the organizers of the project, guarantees its continuity and quality, so that the senior students can share their experiences with the younger pupils. A similar requirement, for the same purpose as mentioned above, will be applied in the selection of students participating in the project students will be selected from the 1st to the 4th year of study. The project will not include fifth-year students. This is because they will be focused on writing their master's theses and preparing for the entrance exams for various legal professions.

\section{PROJECT RECIPIENTS}

The recipients of the workshops prepared under the pilot project will be students at Warsaw primary schools located in the Mokotów district. Such a solution should ensure the possibility of conducting workshops either face to face, considering the development situation caused by COVID-19, or if required in an online, hybrid or asynchronous form. Additionally, this solution is supported by the fact that:

a) in the case of online or hybrid education, school students in Warsaw have the least problems with access to the Internet and technical equipment;

b) very restrictive legal regulations related to students travelling during classes to an educational institution by private transport, e.g., the car of another project participant even as a passenger (apart from additional costs related to insurance, it could expose project participants to many legal consequences in the event of an accident).

Younger classes will be devoted to animal rights classes, and older classes will be devoted to fake news or issues related to refugees or the protection of personal data. All topics will contain a substantive component related to the rights and obligations of children and young people in each aspect.

\section{WHERE AND WHY THE NAME `STREET LAW SCHOOL CLINIC`CAME FROM}

The Street Law School Clinic originated from the first meeting of the Secondary School students' representatives and the Director of the Student Legal Clinic at Lazarski University with Leah Wortham, a retired professor from The Catholic University of America. The purpose of the meeting was; firstly, to establish a good working relationship, as it is important for the success and quality of any project; secondly, to present the initial assumptions for the project; and lastly to allow the students to assess their English language skills, and develop confidence from successfully talking to a native speaking expert. During the meeting with the Professor the scope of the clinics operations were discussed and agreed upon by the participants. It was noted that participants of the project, students at this Clinic, cannot be provided with legal advice due to the regulations related to the protection of clients' personal data and responsibility for their breach, the emotional maturity of the project participants and other ethical factors. Additionally, we wanted to avoid controversy among law practitioners: judges, prosecutors, legal advisers, and the academic community by not contradicting the standards imposed by the University Law Clinics Foundation for the creation of typical Law Clinics. Hence, after meeting the Professor and following her suggestions, the organizers decided to name the project: Street Law School Clinic.

\section{EXPECTED EFFECTS}

The most important aim of the project, in these difficult times for democratic states, is the building and the maintaining of the positive participation of members of society in public life. In addition, the project is expected to be a bridge that connects academia with schools, a bridge that will enable the sharing of knowledge and teaching skills between different levels of education.

From the universities' point of view, it is worth paying attention to improving the teaching qualifications of academic teachers - in Poland, academic teachers do not need to have pedagogical qualifications, and only recently special units have been formed to support academics in their didactic work in order to improve the quality of education in Polish universities. Thanks to the project, tutors from the Law Clinic of Lazarski University will stay in touch with both high school and primary school students (who may become Lazarski students at some time in the future), which should help them design classes in the years to come. In addition, the project should help in the identification of talented students, and then create opportunities for their individual development.

A student participating in the project will undoubtedly be able to work on the vital 21 st century skill of communication. It is worth noting that it is cross-generational communication that will assist the student a future lawyer - to communicate with clients for whom legal terminology may be unclear. In addition, they may well acquire and improve teamworking and time management skills. The project will help students to work on developing empathy and taking responsibility for the success of the project, but most of all being responsible for 
other people. Students, pupils, teachers, and academics will be able to make new friends, which we hope will result in future collaborations. For students, who take an active part in the activities of the Clinic, the project should help to: develop interests that may make it easier for these participants to identify their future career path ; the ability to work in a team, consisting of people of different ages, with different levels of knowledge (learning to present your ideas to more experienced people and to draw conclusions, critical thinking); building self-confidence in support of achieving short- and long-term goals, developing public speaking skills; learning the law by teaching others; having greater self-confidence when they transition from high school to university (a high school student will know what to expect).

\section{SUMMARY}

The pilot project described in this article is undoubtedly an innovative project, which may have an impact on further changes to Polish law clinics, who are facing many challenges in the 21 st century. Undoubtedly, its great advantage is that the pilot project can be implemented without major disruptions in both classroom and online learning. One should agree with the statement that from the university's perspective the project may require greater involvement of employees, but the additional costs for the project will be low i.e., the purchase of any supplies needed to conduct workshops (paper, felt-tip pens, materials for building houses for homeless animals during the workshops on animal rights prepared for younger students). The initiators of the pilot project are sincerely believe that it will be successful, and that it will bring many benefits. Since Melbourne Law School has offered 'Street Law' as an elective subject to their Juris Doctor students since 2012, why not give our students a chance?

\section{References:}

1. Sample Handbook for Street Law Clinic. URL: https://www.researchgate.net/publication/343704758 Sample_Handbook_for_Street_Law_Clinic [accessed Aug 08, 2021].

2. David McQuoid-Mason, 'Street Law as a Clinical Program '(2008) 17 (1) Griffith Law Review 27, 27. 